\title{
Impact of Tax Revenue on Economic Development in Nigeria
}

\author{
Uket E. Ewa ${ }^{1}$, Wasiu A. Adesola ${ }^{1}$, \& Etim N. Essien ${ }^{1}$ \\ ${ }^{1}$ Department of Accountancy, Faculty of Management Science, Cross River University of Technology, Calabar, \\ Nigeria \\ Correspondence: Uket E. Ewa, Department of Accountancy, Faculty of Management Science, Cross River \\ University of Technology, Calabar, Nigeria.
}

\author{
Received: April 7, 2020 \\ Accepted: May 7, 2020 \\ Online Published: May 8, 2020 \\ doi:10.5539/ibr.v13n6p1 \\ URL: https://doi.org/10.5539/ibr.v13n6p1
}

\begin{abstract}
There has been conflicting preposition as to the extent of tax contribution to the development of Nigerian economy. This study is to determine the impact of taxation proceeds on the development of Nigerian economy. The study explored the impact of three tax income streams - Income tax from companies' profits, income tax from petroleum companies profits and Value Added Tax on economic development represented by Gross Domestic Product (at current basic prices) growth for the period 1994 to 2018. The study applied Ordinary Least Square statistical tool with the help of SPSS 20.0. The study revealed a positive relationship with a coefficient of determination of $99.2 \%$ of the variation in economic development attributable to the tax income streams studied. Also although the study revealed the existence of significant effect of taxes from companies' profits and Value Added Tax on Gross Domestic Product Growth, there is little or no significant impact of taxes on profits of Petroleum companies on Gross Domestic Product growth in Nigeria due to restriction by Organization of Petroleum Exporting Countries production ceiling on Nigeria's production/sales and the global price shocks of crude oil over the decade. Also the study revealed tax payers apathy to tax payment and presence of tax leakages due to corruption and administrative inefficiencies by the tax authorities.
\end{abstract}

Keywords: economic development, gross domestic product growth, petroleum profit tax, company income tax, value added tax

\section{Introduction}

The world over, economic development is an important construct for discourse as its relevance can never be over-emphasized. Development in a country spans across array of visible outputs as indicators. These include critical infrastructures, human capital improvement, advancement in technology, expansion in commerce and so on. Most often development and growth are used inter-changeably; however, the difference between these constructs is that while growth is concerned about the total output of a nation within a defined period, development is concerned about visible output in an economy.

Economic development in Nigeria started before colonial era although many economic activities that took place during that time were not documented. Since then Nigeria has undergone numerous economic developmental plans all geared toward visible outputs. Notable amongst them are the Structural Adjustment Programme (SAP) of the then military administration of Ibrahim Badamosi Babangida in the 80's, the Sure-P programme of the Goodluck Ebele Jonathan's administration, and the current N-Power programme of the Mohamadu Buhari's administration.

Notwithstanding, developmental programmes in Nigeria or anywhere in the world may not be fully achieved without the contribution of revenue generated from taxes to finance such programmes. Although Nigeria in particular may be adjudged as a mono-economic nation, the tax revenue would play a critical role to her development. The drop in the prices of crude oil in the global market, inefficient agricultural sector making Nigeria a mono-product country and the various tax reforms introduced to shore up tax proceeds and the anticipated input to economic growth calls for critical assessment taxation has on economic growth in Nigeria.

\subsection{Statement of Problem}

Economic development has remained a serial problem bedeviling the Nigerian state since independence as several efforts geared toward economic recovery have failed to yield significant results. There still persist in Nigeria the problems of unemployment, high mortality rate occasioned by poor health care system, brain drain as 
a result of poor educational funding, lack of critical infrastructures, high inflation rate, insecurity etc.

The existence of all these notable problems and recent drop in the prices of crude oil in the global market necessitate an assessment of the effect that tax revenue has on economic development. Also the drive by the management of the Federal Inland Revenue Service (FIRS) and the different tax reforms introduced by government to shore up revenue from taxation and the projected impact on economic growth demands a critical examination of the influence of taxation on Nigeria's economic growth. The study is therefore to appraise the correlation between proceeds from taxation and economic development and growth.

\subsection{Objective of the Study}

The main reason for this study is to examine the effect proceeds from taxation has on Nigeria economic development measured by Gross Domestic Product (GDP) growth. The specific objectives are:

i. To examine the effect of Company Income Tax (CIT) on economic development,

ii. To examine the effect of Petroleum Profit Tax (PPT) on economic development and

iii. To examine the effect of Value Added Tax (VAT) on economic development.

Research Questions: In Other to Address the Above Objectives, We Considered the Below Research Questions:

i. How does Company Income Tax revenue impact on GDP growth in Nigeria?

ii. What impact does Petroleum Profit Tax revenue have on Nigeria GDP growth?

iii. What effect does Value Added Tax revenue have on Nigeria GDP growth?

iv. What combined effect does of tax revenues measured by tax on companies' profits, tax on profits of petroleum companies and Value Added Taxes on Nigeria GDP growth?

Hypothesis: The following hypothesis were tested to establish the relationship of taxation and economic development:

i. Company Income Tax revenue has no significant effect on Nigeria GDP growth

ii. Petroleum Profit Tax revenue has no significant effect on Nigeria GDP growth.

iii. Value Added Tax revenue has no significant effect on Nigeria GDP growth.

iv. The combined tax revenue streams from CIT, PPT and VAT has no significant effect on Nigeria GDP growth.

\section{Review of Literature}

\subsection{Theoretical Review}

The influence of taxation on economic growth has not only being paramount to the government, tax experts and tax officials but has overtime interested both academics and researchers. Myles (2009) linked taxation to growth through the decisions of individual economic agents. He opined that a change in a tax system modifies optimal choices through the equilibrium of the economy ultimately affecting the rate of growth. The neoclassical growth model of Solow (1956) provided the theoretical link between economic growth and tax revenue. The model hypothesizes a steady operation that links productivity to the contributions of labor and capital which are viable.

As effect of taxation on economic development encompasses both effect of tax revenue generation and taxation policies on the economy, this study reviewed tax theories that addresses influence of tax revenue on economic growth. Bhartia (2009) postulates some tax theories are built on the hypothesis that needless any connection between payment of tax by citizens and benefits accruable from the state while other theories are based on a link between rendering of service and payment of taxes. The former group includes; socio-political theory and the expediency theory while the later include; the cost of service theory and the benefit received theory. Socio-Political theory postulates social and political objectives as paramount indictors in selecting taxation policies. The theory discouraged tax policy and planning arrangement based on individuals' consideration and benefits rather than the curing the problems of the public as a whole (Bhartia, 2009). In contrast, expediency theory emphasizes that each tax scheme must exhibit reasonableness and should be the main evaluation the government uses in selecting a tax plan, (Bhartia, 2009). There is also the Faculty theory of taxation which postulated that a taxable person should suffer tax based on his capability to pay. The latter group includes; cost of service theory. This theory highlights the partial contractual link between the government and the people. Semi-contractual relation by way of the state providing the citizens social/welfare services as well as protection of lives and property in lieu of citizens reciprocating by the payment of taxes. Here government cost of providing certain services to the people is to meet the ultimate recipient of the service (Jhingan, 2009). Taxation is thus 
seen as quid pro quo service. That is, citizens who failed to employ the services the government renders be excluded from payment of tax. However, Jhingan (2009) posit that the cost of service theory foists some limitations on administration services. This is premised on the fact that since the primary responsibility of the state is the provision of social services to the needy, the strict use of the theory will mean the administration will not take on social service activities like provision of healthcare, educational and humanitarian services. According to Ojong, Anthony and Arikpo (2016), the theory has despoiled the precise explanation and canons of tax. Benefit Received Theory arose from the shortcomings observed in the cost of service theory. This theory is the transformation of the cost of service theory as it ensues on the postulation that essentially there is a swapping link between taxable persons and the State. The State makes available infrastructure and facilities to the society and the tax payers are obligated to pay for the services sine qua non to the benefits received (Bhartia, 2009). The ability of taxation to impact economic growth is a benefit to the citizens.

This study is anchored on the Benefit Received Theory and Socio-Political Theory. This is premised on the fact that while tax payers expect judicious and transparent use of the taxes paid for the setting up of infrastructural facilities, social and health services, the State retains the right to decide the tax policies it operates in the country. Many individuals and organizations evade tax not only because of their selfish motive but because there is no corresponding response by government in terms of good governance and transparency in the setting up of infrastructural facilities and social services to the citizenry, (BBC, 2019; Oyedele, n. d ; Ojong et al. 2016).

\subsection{Conceptual Framework}

\subsubsection{Taxation and Economic Development}

As Nigeria population increases over the years so does needs increase in the same proportion and such needs must be met if the envisaged development must be attained. To achieved the obvious task therefore, governments globally and indeed Nigeria requires increased revenue which taxation is a veritable source.

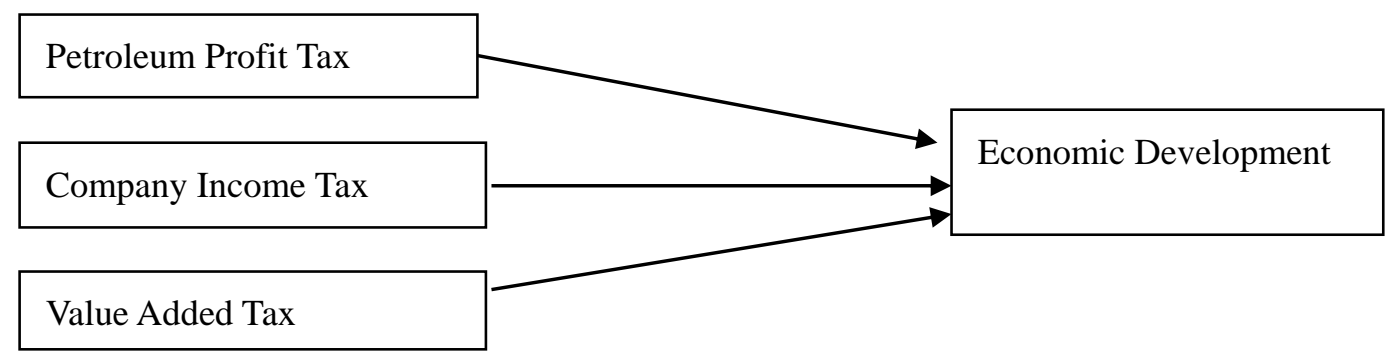

Figure 1. Conceptual framework depicting variables relationship

To address the increasing demands of the citizens from government calls for increased revenue generation. Taxation as one source of revenue generation for government is derived from profits from oil and gas exploration, profits from limited liability companies operating in Nigeria, proceeds from value added on goods and services as well as personal incomes of individuals and partnerships. Generally, taxation is a fiscal liability laid on an individual or person, organization or assets to support government. It is also a charge on profit or gain to fund the provision of social amenities and enhancement of industrial productivity. It is an opportunity to generate revenue for government expenditure for socio-economic development. It is also an instrument for management of the State economy through economic policy pronouncements as well as vehicle for controlling and discouraging certain anti-social habits or behaviors. This is through assisting in the regulation of consumption pattern of citizens of a State. Taxation similarly serves as an apparatus of government for income redistribution in the nation State. Thus, taxation constitutes an instrument for monetary policy and macro-economic management.

Eze, Iorwuese and Abba (2016) postulated that in Nigeria in terms of public revenue generation, tax revenue is ranked next to revenue from petroleum sector.

\subsubsection{Personal Income Tax}

Personal Income Tax is governed under Personal Income Tax Act (PITA) 2011. This Act regulates the taxation of individuals, sole traders, partnership, executors and trustees. Incomes charged under this Act are global incomes from employment, trading, business, vacation, trust etc. According to Afuberoh and Okoye, (2014) income tax is 
used all over the world by governments to stimulate adversely or positively specific types of business ventures with a view to meeting government desired objectives. As an emerging nation, Nigeria major economic goal is to enhance the rate of economic growth thereby improving per capita income and boasting living standard of citizens. Nigeria has for the past three decades carried out various reforms in personal income tax management to actualize this objective of GDP growth.

\subsubsection{Company Income Tax}

The Company Income Tax is regulated by the Company Income Tax Act and managed by Federal Inland Revenue Service. The law deals with the assessment and collection of taxes from all companies operating as limited liability companies with the exception of those operating in the petroleum sub sector. Section 40(1) of Company Income Tax Act (CITA) specifies a tax rate of 30\% of chargeable profit while Section 40(6) stipulates a tax rate of $20 \%$ for companies operating in either the manufacturing, agricultural, mining sectors or the company is completely into export trade and earns a total gross turnover of below one million naira for the first five (5) years of assessment.

\subsubsection{Petroleum Profit Tax}

The Petroleum Profit Tax is regulated by the Petroleum Profit Tax Act (PPTA). It is under the administration of the Federal Inland Revenue Board and the tax is on profits of companies engaged in petroleum operations. The Act defined Petroleum Operations as "the winning or obtaining and transportation of petroleum or chargeable oil in Nigeria by or on behalf of a company for its own account by any drilling, mining, extracting or other like operations or processes, not including refining at a refinery, in the course of a business carried on by the company engaged in such operations, and all operations incidental thereto and any sale of or any disposal of chargeable oil or on behalf of the company". The tax rate on chargeable profit in any accounting period is $85 \%$ of the company's chargeable profit.

\subsubsection{Tax Reforms in Nigeria}

In an effort to increase tax revenue as a composite revenue source, various reforms aimed at expanding the tax base, enhance efficiency and effectiveness in tax administration have been embarked upon by government. According to Herbert, Nwarogu and Nwabueze (2018), emerging nations' residents' lethargy towards taxation is a combination of causes among which is lack of transparency and accountability by governments and their agencies and the bureaucratic inertia by various tiers of government of the nations. Therefore it is essential for tax reforms as it is a fundamental fiscal policy strategy designed to enhance tax administration. Eze et al. (2016) stated that, the Joint Tax Board (JTB) in 1999 approved a protocol for efficient tax administration which requires all staff to among other things ensure prompt and correct payment of their salaries, exhibit honesty and impartiality in the discharge of their services, be courteous and professional in service delivery and avoid collusion with tax payers in the process of evading taxes and other forms of tax planning.

Table 1. Reforms highlights

\begin{tabular}{|c|c|c|c|}
\hline CITA & PITA & PPTA & VAT \\
\hline $\begin{array}{l}>\text { Raising of the limit of } \\
\text { external loan that is } \\
\text { suitable for tax relief } \\
\text { from }=\mathrm{N}=150,000 \text { to } \\
=\mathrm{N}=5 \text { million } \\
>\text { Amendment of } \\
\text { conditions for allowing } \\
\text { tax freedom on profit } \\
\text { earned from exporting } \\
\text { manufactured goods } \\
>\text { Substitution } \\
\text { allowances } \\
\text { investment profits with } \\
\text { investment tax credit } \\
>\text { Done away with the } \\
\text { ambiguities in sections } \\
40 \mathrm{~b}, 47,50,51,54 \& 59 \\
\text { in the self-assessment } \\
\text { filing system. }\end{array}$ & 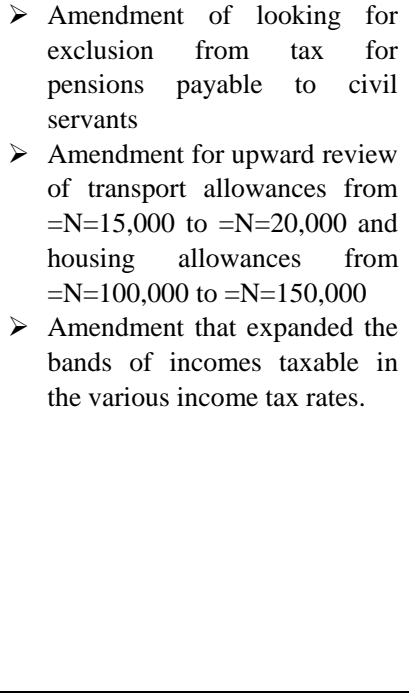 & $\begin{array}{l}\text { Revision that provided for } \\
\text { interest on intercompany } \\
\text { credits within the oil } \\
\text { industry as permissible } \\
\text { deductions } \\
>\text { Review of incentives like } \\
\text { calculation of investment } \\
\text { tax credit on qualifying } \\
\text { capital expenditure rather } \\
\text { than on chargeable profits }\end{array}$ & $\begin{array}{l}>\text { Inclusion of assessment for } \\
\text { services in the definition of } \\
\text { assessable value } \\
>\text { Multiple registrations of VAT as } \\
\text { against central registration } \\
>\text { Substitution of taxable person in } \\
\text { section 8A and 10A. } \\
>\text { Authorizing the Accountant } \\
\text { General to deduct at source VAT } \\
\text { on contracts not remitted by } \\
\text { MDAs from allocations due to } \\
\text { the MDAs. } \\
>\text { Modification allowing injured } \\
\text { tax payers to petition to the VAT } \\
\text { tribunal and empowerment of } \\
\text { government to arraign VAT } \\
\text { debtors before the VAT tribunal. } \\
>\text { Restraining of exempted food } \\
\text { items to locally produced ones } \\
\text { as an anti-avoidance strategy. }\end{array}$ \\
\hline
\end{tabular}


One of the essential components of the national tax policy which came to fruition through the co-operation between the federating units and the central government is the introduction of Tax Payers Identification Number (TIN). TIN is a nation-wide electronic database system for the registration and storage of data of tax payers in Nigeria which is aimed at expanding the tax base of the country with attendant prospect for increase in tax generated revenue. Also the following sections; 3 (1) (b) (ii)-(xii) of the Personal Income Tax Act of 2004 that provided employees with free tax allowances etc where deleted. This gave room to uniform consolidated relief allowance based on consolidated gross salary. Of interest also is the restructuring of Federal Inland Revenue Service (FIRS) which as an autonomous body with a board having overall control of its operation and the provision of $4 \%$ of collected revenue proceeds from all non-oil business in the preceding year as administrative charge for the running of the board and institution of a clear tax refund procedure.

\subsubsection{Economic Development}

Feldman and Francis, (2003) as cited in Okeke, Mbonu and Ndubuisi, (2018) opined that, economic development entails combined action and all-encompassing, long-term investment. According to Okeke et al. (2018), economic development talks about the critical conditions needed for the micro economic working of the economy. Furthermore they stated that economic development is centered around government and though it is undoubtedly feasible to have economic advances without development in the immediate or near term, economic development generates the environments that enable long-run economic growth, (Okeke et al, 2018). That the cardinal objective of economic development is employment generation but for progress, what is important is the amount of jobs created in the economy. Thus the focus of economic development is career advancement opportunities, wages and working conditions.

\subsubsection{Taxation and GDP Growth Rate}

GDP remains one of the yardsticks for measuring economic development of any country and indeed Nigeria. However, some authors hold different views about GDP as a predominant measure of development. Manish and Andre (2019) argued that the frequent application of GDP as a proxy for measuring economic growth is majorly due to easy quantification of manufactured goods and activities than a multi-dimensional index can measure other welfare achievements.

As Lawal (2011) cited in Benyin and Ugochukwu, (2015) opined, development is a necessary requisite to the development of any developing nation. For the development to be certain, he postulated that there must be guaranteed social, political and economic stability in the nation. However, he opined that purposeful and evidenced based development may just be a mirage without tangible corresponding revenue generation as the driver of economic development. It is therefore essential to generate revenue as it is a catalyst to economic development and tax remains a viable option in actualizing this objective.

Nwokoye and Rolle (2015) in their study posited that VAT and CIT clearly and pointedly stimulate investment in Nigeria and recommended a review of tax policy and administration to expand the tax base.

\subsubsection{Nigeria Economy and Performance Indicators}

Looking at Nigeria's macroeconomic and financial conditions since 1994 when Value Added Tax regime was introduced, GDP annual growth rate rose steadily over the years. The country witnessed a decline in the rate of exchange as exchange rate depreciated from average of $=\mathrm{N}=21.89$ to a dollar in 1994 to an average of $=\mathrm{N}=306.08$ to a dollar in 2018 arising from the global economic meltdown and drop in crude oil prices in the global market. Inflation has remained majorly at double digit figure from a peak of $72.8 \%$ in 1995 to low ebb of $5.4 \%$ in 2007. The external reserves which grew in tandem with oil price increases from 2004 reached a peak of $\$ 51.33$ million in 2007 but have since declined to $\$ 42.59$ million in 2018 due to fall in oil prices arising from the global economic meltdown and no close buffer revenue earning stream to ameliorate the impact of oil revenue to the national revenue. 
Table 2. Selected Macroeconomic and Financial Indicators

\begin{tabular}{|c|c|c|c|c|}
\hline Years & $\begin{array}{r}\text { GDP at Current Basic Prices } \\
\text { (N' Billion) }\end{array}$ & $\begin{array}{l}\text { Exchange } \\
\text { Rate }\end{array}$ & $\begin{array}{l}\text { Inflation } \\
\text { Rate }\end{array}$ & $\begin{array}{l}\text { External Reserves } \\
\text { (\$: Million) }\end{array}$ \\
\hline 1994 & $1,762.81$ & 21.89 & 57 & 1.66 \\
\hline 1995 & $2,895.20$ & 70.36 & 72.8 & 1.44 \\
\hline 1996 & $3,779.13$ & 69.84 & 29.3 & 4.07 \\
\hline 1997 & $4,111.64$ & 71.8 & 8.5 & 7.58 \\
\hline 1998 & $4,588.99$ & 76.81 & 10 & 7.11 \\
\hline 1999 & $5,307.36$ & 92.34 & 6.6 & 5.45 \\
\hline 2000 & $6,897.48$ & 101.65 & 6.9 & 9.91 \\
\hline 2001 & $8,134.14$ & 111.94 & 18.9 & 10.42 \\
\hline 2002 & $11,332.25$ & 120.97 & 12.9 & 7.68 \\
\hline 2003 & $13,301.56$ & 129.36 & 14 & 7.47 \\
\hline 2004 & $17,321.30$ & 133.5 & 15 & 16.96 \\
\hline 2005 & $22,269.98$ & 132.15 & 17.9 & 28.28 \\
\hline 2006 & $28,662.47$ & 128.65 & 8.2 & 42.3 \\
\hline 2007 & $32,995.38$ & 125.83 & 5.4 & 51.33 \\
\hline 2008 & $39,157.88$ & 118.57 & 11.6 & 53 \\
\hline 2009 & $44,285.56$ & 148.9 & 11.5 & 42.38 \\
\hline 2010 & $54,612.26$ & 150.3 & 13.7 & 32.34 \\
\hline 2011 & $62,980.40$ & 153.86 & 10.8 & 32.34 \\
\hline 2012 & $71,713.94$ & 157.5 & 12.2 & 32.64 \\
\hline 2013 & $80,092.56$ & 157.31 & 8.5 & 43.83 \\
\hline 2014 & $89,043.62$ & 158.55 & 8.1 & 34.24 \\
\hline 2015 & $94,144.96$ & 193.18 & 9 & 28.28 \\
\hline 2016 & $101,489.49$ & 253.49 & 15.7 & 26.99 \\
\hline 2017 & $113,711.63$ & 305.79 & 16.5 & 39.35 \\
\hline 2018 & $127,762.55$ & 306.08 & 11.4 & 42.59 \\
\hline
\end{tabular}

Source: CBN Statistical Bulletin 2018.

\subsection{Empirical Review}

Adereti, Sanni and Adesina (2011) in their studies "value-added tax and economic growth of Nigeria", adopted GDP as a measure for Economic Growth on Value-Added Tax (VAT). The study revealed a considerable share of the difference in economic growth measured by GDP is accounted by revenue from VAT as the coefficient of determination was put at 0.950544 . The study revealed the presence of a positive and significant correlation between revenue from VAT and GDP. In fact, the data showed fluctuation in both variables (VAT and GDP) studied over the study period although VAT revenue was more stable. There was however none existence of causation between GDP and VAT revenue.

Also, Onaolapo, Aworemi and Ajala (2013) in examining impact of VAT on revenue generation using stepwise regression analysis found that VAT has statistically significant effect on revenue generation in Nigeria.

Ojong et al. (2016) in their study on the impact of tax revenue on economic growth: Evidence from Nigeria, considered as independent variables, PPT, None Oil Revenue (NOR) and CIT while GDP as the dependent variable. The result of the study reported a significant and very positive relationship between the independent variables under study and economic growth. Also, while PPT and CIT had positive impact on the economic performance, an increase in NOR does not lead to a rise or improvement in economic growth as earlier postulated. However, the study revealed that the most major challenge as regards tax leakages is the dearth of transparency and good governance by officials which significantly discourages the citizenry from conforming willingly with their tax responsibilities

Also, Ogbonna and Appah (2012) in investigating the impact of tax reform on economic growth in Nigeria employed time series analysis for the period 1981-2007. The study revealed variations in all the income taxes having positive coefficient implying that tax reforms stimulate economic growth.

However, Okeke et al. (2018) study which examined the connection between tax revenue and economic development measured by labour force, infant mortality and fixed capital formation in Nigeria between the period 1994 - 2016 reported tax revenue has a statistically important correlation between labor force, infant mortality and gross fixed capital formation. It was recommended for the government to increase tax revenue allocation to the critical sectors of the economy like agriculture and industry so as to improve on the wellbeing of the citizenry. 
But Appah and Ebiringa (2012) in their study examined the connection between petroleum profit tax and economic growth in Nigeria by obtaining data covering GDP and PPT between the period 1970 to 2010. The study ascertained using Granger causality the direction of connection between the two variables and established the presence of a long run equilibrium relationship between gross domestic product (GDP) and petroleum profit tax and also, the existence of positive and significant relationship between PPT and economic growth.

Worlu and Emeka (2012) in examining the effect of revenue from taxation on economic growth of Nigeria from the perspective of infrastructural development from 1980 to 2007, revealed revenue from taxes stimulating growth in improvement of infrastructure. However, the study revealed the absence of independent effect on improvement in infrastructural development and foreign direct investment due to revenue from taxation but just permitting the development in infrastructural and foreign direct investment to positively react to increases in productivity. Uzoka and Chiedu (2018) studied the effect of revenues from taxation on the growth of the economic in Nigeria between 1997 -2016. The unit root test result revealed incomes from company tax, customs and excise duty and gains from sale of capital assets are stationary at level. While Real Gross Domestic Product (RGDP), Petroleum Profit Tax (PPT), Value Added Tax (VAT) and RDT are stationary at first order, that is after first difference. The co-integration tests showed that a long run relationship existed between the economic growth and RGDP, PPT, VAT and RDT CIT, CED. The results obtained from the analysis of the model revealed CGT and EDT have no major effect on economic growth but there is a significant effect from PPT, CIT, VAT and CED on the growth of Nigeria economic. The study recommended to boost the growth of Nigeria economic, the administration need to ensure the tax revenue generated are channeled towards building capital stock that can create more jobs which will produce more income to government through other forms of taxes.

Although there was a significant connection between revenue from non-oil sector and Nigeria economic growth, there is no similar connection between income from company taxation and Nigeria economic growth. The study suggested the administration to endeavor providing welfare services and amenities across the country. Also government should intensify efforts to complete the overhaul of the tax system so as ameliorate the incidence of tax evasion and avoidance. Also in order to expand government tax base, efforts should be made in creating conducive environment for private enterprises, creativity and employment generation as well as encourage made-in-Nigeria goods using tax proceeds.

Okwara and Amori, (2017) examined the effect of revenue from taxation on growth of Nigerian economic from 1994 to2015. Gross Domestic Product (GDP) was used as a variable representing economic growth while Value Added Tax (VAT) and non-oil income (tax) was used to measure tax revenue. The result showed non-oil income having substantial effect on gross domestic product but value added tax having adverse association and statistically insignificant for the review period. Therefore, it was concluded that revenue from taxation have positive effect on economic growth of Nigerian and thus recommended for the nation to broaden its revenue sources out of crude oil to other sectors of the economy such as agriculture and extractive industries.

\section{Methodology}

\subsection{Research Design}

Longitudinal research design was considered suitable in this study since the data used for the study was time series data. The scope of this study spanned from 1994-2018, a 25-year period. The data were sourced from the Central Bank of Nigeria (CBN) 2018 Statistical Bulletin and Federal Inland Revenue Service (FIRS).

The independent variables for this study consist of revenues from; Company Income Tax (CIT), Petroleum Profit Tax (PPT) and Value Added Tax while the dependent variable is Gross Domestic Product Growth (GDP) at current price.

\subsection{Techniques of Data Analysis}

Based on the perceived causal relationship between the dependent and independent variables of the research, a Multiple Regression model which is stochastic in nature was specified to link tax revenue and economic growth. In estimating the relationship between tax revenue and economic growth, the study adopted economic approach and employed the Ordinary Least Square (OLS) technique. The model was selected because it has some ideal properties. Its computational method is objectively modest and it has the BLUE property, Ojong et al. (2016).

\subsection{Model Specification}

The functional model of this study is specified thus;

$$
\text { Economic development } \quad=f \text { (taxation) }+\tau
$$

Where, 
Economic development $=$ GDP $($ Dependent Variable $)$

Taxation $($ Explanatory/Independent Variable $)=$ PPT, CIT, VAT

$$
\mathrm{GDP}=\int(\mathrm{PPT}, \mathrm{CIT}, \mathrm{VAT})
$$

Where

$$
\mathrm{GDP}=\beta \mathrm{o}+\beta_{1} \mathrm{PPT}+\beta_{2} \mathrm{CIT}+\beta_{3} \mathrm{VAT}+\tau
$$

The logarithmic transformation of equation 2 is designed to bring the variables to the same base hence the model becomes:

$$
\log (\mathrm{GDPG})=\beta \mathrm{o}+\beta_{1} \log (\mathrm{PPT})+\beta_{2} \log (\mathrm{CIT})+\beta_{3} \log (\mathrm{VAT})+\tau
$$

Where:

$$
\begin{gathered}
\beta_{0}=\text { Constant term (Intercept); } \\
\beta_{1-3}=\text { Coefficient of parameters of taxation; } \\
\mu=\text { Stochastic error term } \\
\text { A priori }=\beta_{0}>0, \beta_{1}>0, \beta_{2}>0, \beta_{3}>0 \\
\mu=\text { Error term (Stochastic Term). }
\end{gathered}
$$

\begin{tabular}{|c|c|c|c|c|c|c|c|c|}
\hline DATE & CIT(Billion) & PPT(Billion) & VAT(Billion) & $\begin{array}{l}\text { GDP at Current } \\
\text { Basic Prices } \\
\text { (N' Billion) }\end{array}$ & LOGCIT & LOGPPT & LOGVAT & LOGGDP \\
\hline 1993 & 95.54 & 59.21 & & $1,259.07$ & & & & \\
\hline 1994 & 12.28 & 42.83 & 7.26 & $1,762.81$ & 1.089022 & 1.631778493 & 0.860996437 & 3.246206 \\
\hline 1995 & 21.88 & 42.86 & 20.76 & $2,895.20$ & 1.340008 & 1.632031901 & 1.317248268 & 3.461679 \\
\hline 1996 & 22.00 & 76.67 & 31.00 & $3,779.13$ & 1.342423 & 1.88460847 & 1.491361694 & 3.577392 \\
\hline 1997 & 26.00 & 68.57 & 34.00 & $4,111.64$ & 1.414973 & 1.836159483 & 1.531478917 & 3.614015 \\
\hline 1998 & 33.30 & 68.00 & 36.00 & $4,588.99$ & 1.522444 & 1.832508913 & 1.556302501 & 3.661717 \\
\hline 1999 & 46.20 & 164.30 & 47.10 & $5,307.36$ & 1.664642 & 2.215637563 & 1.673020907 & 3.724879 \\
\hline 2000 & 51.10 & 525.10 & 58.50 & $6,897.48$ & 1.708421 & 2.720242018 & 1.767155866 & 3.838691 \\
\hline 2001 & 68.70 & 639.20 & 91.80 & $8,134.14$ & 1.836957 & 2.805636766 & 1.962842681 & 3.910312 \\
\hline 2002 & 89.10 & 392.20 & 108.60 & $11,332.25$ & 1.949878 & 2.593507589 & 2.035829825 & 4.054316 \\
\hline 2003 & 114.80 & 683.50 & 136.40 & $13,301.56$ & 2.059942 & 2.834738519 & 2.13481437 & 4.123903 \\
\hline 2004 & 113.00 & $1,183.60$ & 159.50 & $17,321.30$ & 2.053078 & 3.073204956 & 2.202760687 & 4.23858 \\
\hline 2005 & 140.30 & $1,904.90$ & 178.10 & $22,269.98$ & 2.147058 & 3.279872182 & 2.250663919 & 4.34772 \\
\hline 2006 & 244.90 & $2,038.30$ & 221.60 & $28,662.47$ & 2.388989 & 3.309268104 & 2.345569756 & 4.457314 \\
\hline 2007 & 275.30 & $1,600.60$ & 289.60 & $32,995.38$ & 2.439806 & 3.204282813 & 2.461798558 & 4.518453 \\
\hline 2008 & 420.60 & $2,060.90$ & 401.70 & $39,157.88$ & 2.623869 & 3.314056919 & 2.603901832 & 4.592819 \\
\hline 2009 & 600.60 & 939.40 & 481.40 & $44,285.56$ & 2.778585 & 2.972850556 & 2.682506086 & 4.646262 \\
\hline 2010 & 666.06 & $1,480.36$ & 564.89 & $54,612.26$ & 2.823513 & 3.170367342 & 2.751963887 & 4.73729 \\
\hline 2011 & 659.60 & $3,070.59$ & 659.15 & $62,980.40$ & 2.819278 & 3.487221973 & 2.818984256 & 4.799205 \\
\hline 2012 & 816.52 & $3,201.32$ & 710.56 & $71,713.94$ & 2.911966 & 3.505328952 & 2.851598311 & 4.855604 \\
\hline 2013 & 963.55 & $2,666.37$ & 802.69 & $80,092.56$ & 2.983875 & 3.425919926 & 2.904547041 & 4.903592 \\
\hline 2014 & $1,180.41$ & $2,453.95$ & 802.96 & $89,043.62$ & 3.072032 & 3.389865179 & 2.904696399 & 4.949603 \\
\hline 2015 & $1,229.02$ & $1,097.95$ & 635.35 & $94,144.96$ & 3.089558 & 3.040580585 & 2.803014401 & 4.973797 \\
\hline 2016 & 933.54 & $1,157.81$ & 828.20 & $101,489.49$ & 2.970132 & 3.063636584 & 2.918134754 & 5.006421 \\
\hline 2017 & $1,215.06$ & $1,520.48$ & 972.35 & $113,711.63$ & 3.084597 & 3.181981197 & 2.987821904 & 5.055805 \\
\hline 2018 & $1,373.21$ & $2,467.58$ & $1,108.04$ & $127,762.55$ & 3.137738 & 3.392271365 & 3.044555635 & 5.106404 \\
\hline
\end{tabular}

\section{Data Analysis and Discussion}

\subsection{Data Analysis}

Table 3. Regression Analysis Data

Source: Researcher's Computation from CBN Statistical Bulletin, 2018

Table 4. Descriptive statistics

\begin{tabular}{lcc}
\hline Variable & Mean & Standard Deviation \\
\hline LOGGDPG & 4.3361 & 0.57597 \\
LOGCIT & 2.2901 & 0.66634 \\
LOGPPT & 2.8319 & 0.62218 \\
LOGVAT & 2.2745 & 0.61766 \\
\hline
\end{tabular}


Significant at 0.05 level $\mathrm{p}<.05$

Dependent Variable: LOGGDPG

Independent Variables: LOGCIT, LOGPPT, LOGVAT

Source: Researcher's SPSS 20.0 Computation, 2019

Table 4 presents the descriptive statistics of the means values of 4.3361, 2.2901, 2.8319 and 2.2745 for GDPG, CIT, PPT and VAT respectively with their standard deviations of $0.57597,0.66634,0.62218$ and 0.61766 .

Table 5. Inter correlation among the variables (LOGGDP, LOGCIT, LOGPPT, LOGVAT

\begin{tabular}{lrrrr}
\hline & & & & \\
& LOGGDP & LOGCIT & LOGPPT & LOGVAT \\
\hline LOGGDP & 1.000 & 0.995 & 0.895 & 0.992 \\
LOGCIT & 0.995 & 1.000 & 0.879 & 0.987 \\
LOGPPT & 0.895 & 0.879 & 1.000 & 0.911 \\
LOGVAT & 0.992 & 0.987 & 0.911 & 1.000 \\
\hline
\end{tabular}

Significant at 0.05 level $\mathrm{p}<.05$

Dependent Variable: LOGGDPG

Independent Variables: LOGCIT, LOGPPT, LOGVAT

Source: Researcher's SPSS 20.0 Computation, 2019

The Ordinary Least Squares (OLS) results presented in Table 5 revealed positive and significant relationship between the variables under study - CIT, PPT and VAT and economic development. This is evidenced by their correlation coefficients of $0.995,0.895$ and 0.992 respectively Thus the result implies taxation has strong association with economic development of Nigeria.

Table 6 includes the logarithmic transformation of the econometric linear model specified in our model equation. The result suggests that a one percent rise in CIT leads to 0.559 per cent increase in GDP growth which is the proxy for economic development. The probability value (0.000) is less than the test significance level of $\alpha<0.05$. Also one per cent rise in PPT leads to mere 0.026 per cent increase in GDP growth (a proxy for economic development). The PPT probability value of 0.557 is thus greater than the test significance level of 0.05 implying that PPT offers little or no significant impact on GDP growth. The result also revealed a one per cent rise in VAT leads to 0.306 per cent increase in GDPG (a proxy for economic development) in Nigeria. The probability value of the VAT (0.030) is less than the test significance level of $\alpha<0.05$, implying the significant effect VAT revenue has on economic development in Nigeria. Likewise, the Coefficient of determination (adjusted R-Square) shows that 99.2 per cent of the variation in economic development is a result of changes in CIT, PPT and VAT while the remaining 0.08 per cent is due to other factors not included in the model. The F-ratio of 988.467 confirmed the fitness of the model to test the data. The Durbin Watson of 0.978 indicates positive autocorrelation among the variables.

Table 6. Least square regression result model summary of Tax Revenue on GDP (Regression constant and coefficients)

\begin{tabular}{|c|c|c|c|c|c|}
\hline \multirow[t]{2}{*}{ Variable } & \multicolumn{2}{|c|}{ Unstandardized coefficients } & \multirow{2}{*}{$\begin{array}{l}\text { Standardized } \\
\text { coefficient } \\
\text { Beta }\end{array}$} & \multirow{2}{*}{$\begin{array}{c}\text { Stat } \\
\mathrm{t}\end{array}$} & \multirow[t]{2}{*}{ Sig } \\
\hline & B & Std error & & & \\
\hline Constant & 2.288 & 0.051 & & 45.197 & 0.000 \\
\hline LOGCIT & 0.559 & 0.105 & 0.646 & 5.314 & 0.000 \\
\hline LOGPPT & 0.026 & 0.043 & 0.028 & 0.597 & 0.557 \\
\hline LOGVAT & 0.306 & 0.131 & 0.328 & 2.329 & 0.03 \\
\hline $\mathrm{R}$ & 0.996 & & & & \\
\hline $\mathrm{R}$ square & 0.993 & & & & \\
\hline Adjusted $\mathrm{R}^{2}$ & 0.992 & & & & \\
\hline F Ratio & 988.467 & & & & \\
\hline Prob & 0.000 & & & & \\
\hline $\mathrm{D} / \mathrm{W}$ & 0.978 & & & & \\
\hline
\end{tabular}


Significant at 0.05 level $\mathrm{p}<.05$

Dependent Variable: LOGGDPG

Independent Variables: LOGCIT, LOGPPT, LOGVAT

Source: Researcher's SPSS 20.0 Computation, (2019)

\subsection{Discussion of Findings}

Positive and significant relationships between the variables as stated in Table 5 exist between CIT, PPT and VAT and economic development. This is demonstrated by their correlation coefficients of $0.995,0.895$ and 0.992 respectively. Thus the result implies taxation has strong association with economic development of Nigeria. Notwithstanding, the encouraging general relationship, the relationship amongst PPT and GDP is not significant $(\mathrm{p}=0.557)$. This may be attributable to drop in crude oil prices in the global market impacting on taxable profits of oil companies liable to tax. This corresponded with the studies by (Ojong et al., 2016; Uzoka \& Chiedu, 2018) that posited a long run relationship between tax revenue and RGDP and further stated that PPT and CIT have significant effect on economic growth measured by RGDP. Similarly Okeke et al. (2018) study that examined the relationship between tax revenue and economic development measured by infant mortality, labour force and fixed capital formation in Nigeria revealed tax revenue has a statistically significant relationship with economic growth measured by infant mortality, labor force and gross fixed capital formation. In other to determine the individual contributions of the three independent variables under study, Table 5 revealed a correlation value of 0.879 for company income tax (CIT) with PPT indicating positive relationship between the variables with a probability value $(0.000)$ which is less than the test significance level of $\alpha<0.05$. Also there is a positive relationship between CIT and VAT as the study revealed a correlation value of 0.987 with a probability value of (0.000) which is less than the test significance level of $\alpha<0.05$. The same applies between PPT with VAT with correlation value of 0.911 among itself with a probability value of $(0.000)$ which is less than the test significance level of $\alpha<0.05$.

The result of the logarithmic transformation of the econometric linear model in Table 6 suggests that a one percent increase in CIT leads to 0.559 per cent increase in GDP which is the proxy for economic development with a probability value $(0.000)$ which is less than the test significance level of $\alpha<0.05$. This implies a significant effect of CIT on GDP. This is consistent with the works of (Nwaezeaku, 2005; Nwokoye \& Rolle, 2015; Ojong et al., 2016 and Herbert et al. 2018).

The result in Table 6 also revealed a one per cent increase in PPT leads to mere 0.026 per cent increase in GDP with a PPT probability value of 0.557 which is greater than the test significance level of 0.05 implying that PPT offers little or no significant impact on GDP growth. This is consistent with the work of (Ojong et al., 2016). This may be the result of the drop of crude oil prices in the international market and the Organization of Petroleum Exporting Countries (OPEC) quota of crude oil sales Nigeria is required to sell in the international market. Also may be as a result of the ratio of contribution of PPT against other tax revenue streams on GDP growth. The result runs contrary to previous studies by (Ogbonna \& Ebimobowei, 2012; Appah \& Ebiringa, 2012 and Herbert et al. 2018). Similarly, a one per cent increase in VAT leads to 0.306 per cent increase in GDP. The probability value of the VAT (0.030) is less than the test significance level of $\alpha<0.05$. This is partly due to enhanced efficiency in tax collection, administration and advocacy and broadened tax base for VAT collection. The result also runs contrary to the study of Okwara and Amori (2017) which revealed non significance of VAT on economic growth as against other non-oil revenues. From the adjusted R-Square of 99.2 per cent, it is evident that $99.2 \%$ of variation in economic development is a result of changes in CIT, PPT and VAT while the remaining 0.08 per cent is due to other factors not included in the model.

Therefore, based on the results, the null hypotheses are thus rejected while the alternate hypotheses are accepted that there is a significant impact of tax revenue from CIT, PPT and VAT on economic development measured by GDPG.

\section{Summary of Findings and Conclusion}

This study revealed a significant relationship exists between Petroleum Profit Tax and Gross Domestic Product Growth measuring economic development. However, the positive relationship between petroleum profit tax and GDPG is not that significant compared to other variables under study. This is as a result of OPEC production/sales quota as well as continuous drop in crude oil prices at the international market over a decade now which is impacting negatively on the profits subject to tax of the oil companies operating in Nigeria. There is also a significant relationship between Company Income Tax and GDPG. Similarly, there is a significant 
relationship between Value Added Tax and GDPG. This significant result can be attributed to enhanced efficiency in VAT revenue collection, administration, advocacy and the recent broadening of tax base for VAT collection. The ratio of tax revenue to GDPG is still very low compared to other economies as Nigeria depends largely on crude oil export. Although taxation remains a strong socio-political and economic tool for economic development but Nigeria experience is adverse due to tax leakages arising from tax evasion, avoidance and low tax base. This study found that tax leakages are of global concern but the Nigerian experience is cancerous due to corruption in the system. The study collaborated other studies that belief what triggers the noncompliance to a large extent is expedited by the lack of transparency and good governance on the part of the state which highly discourages tax/potential tax payers from complying willingly with their tax obligations.

\section{Recommendations}

It is recommended that Nigerian government should restructure its petroleum sector by intensifying efforts at processing the crude oil and only selling processed oil to the international market. This will overcome the present effect of external shocks arising from price fluctuation of crude oil due to gloat or quota restrictions by OPEC or financial crises in the international market.

Secondly, there should be greater transparency by government on the management and utilization of tax resources so has to give tax payers greater assurance of its application. Also there should be an enhancement of Nigeria's tax administrative management efficiency by blocking leakages in tax revenue collection and the expansion of the nation's tax base to attract more tax revenue.

\section{References}

Adereti, S., Sanni, M., \& Adesina, J. (2011). Value added tax and economic growth of Nigeria. European Journal of Humanities and Social Sciences, 10(1), 456-471.

Afuberoh, D., \& Okoye, E. (2014). Impact of taxation on revenue generation in Nigeria: a study of federal capital territory and selected states. International Journal of Public Administration and Management Research, 2(2).

Appah, E., \& Ebiringa, O. T. (2012). Petroleum profit tax and economic growth in Nigeria. International Journal of Management Science and Business Research, 1(9), 12-22.

Benyin, A. A., \& Ugochukwu, D. A. (2015). Development and its challenges in Nigeria: A theoretical discourse. Mediterranean Journal of Social Sciences, 6(6).

Bhartia, H. L. (2009). Public Finance (14th ed). Vikas Publishing House PVT Ltd, New Delhi.

British Broadcasting Corporation [BBC] News (2019). Nigeria: Why is it struggling to meet its tax targets?, BBC News @. Retrieved from https://www.bbc.com

Central Bank of Nigeria[CBN]. (2018). Statistical bulletin. Retrieved from http://www.cbn.gov.ng/

Eze, N. M., Iorwuses, T. E., \& Abba, W. B. (2016). The challenges and imperative of tax system reform in Nigeria. International Journal of Economics and Finance, 8(3), 151-164. https://doi.org/10.5539/ijef.v8n3p151

Federal Republic of Nigeria. (2002). Petroleum Profit Tax Act.

Federal Republic of Nigeria. (2007). Value Added Tax Act.

Federal Republic of Nigeria. (2011). Companies income -Tax Act.

Federal Republic of Nigeria. (2011). Personal Income Tax Act.

Feldman, M. P., \& Francis, J. (2003). Fortune favors the prepared region: The case of entrepreneurship and the capitol region biotechnology cluster. European Planning Studies, 11(7). https://doi.org/10.1080/0965431032000121337

Herbert, W. E., Nwarogu, I. A., \& Nwabueze, C. C. (2018). Tax reforms and Nigeria's economic stability. International Journal of Applied Economics, Finance and Accounting, 3(2), 74-87. https://doi.org/10.33094/8.2017.2018.32.74.87

Jhingan, M. L. (2009). Money, Banking, international trade and Public Finance. Delhi, Nisha Enterprises.

Lawal, K. T. (2013). Taxation of petroleum profit under the Nigeria's petroleum profit tax act. International Journal of Advanced Legal Studies and Governance, 4(2).

Manish, K. P., \& Andre, C. (2019). Is GDP an adequate measure of development? Retrieved from 
https://www.theigc.org/blog/is-gdp-an-adequate-measure-of-development/

Myles, G. D. (2009). Economic growth and the role of taxation- theory. OECD Economics Department Working Papers No. 713.

Nwaekeaaku, N. C. (2005). Taxation in Nigeria: Principles and practice. Owerri: Springfield Publishers

Nwokoye, G. A., \& Rolle, R. A. (2015). Tax reforms and Investment in Nigeria: An empirical examination. International Journal of Development and Management Review, 10.

Ogbonna, G. N., \& Ebimobowei, A. (2012). Impact of petroleum revenue and the economy of Nigeria. The Social Sciences, 7, 405-411. https://doi.org/10.3923/sscience.2012.405.411

Ogbonna, G. N., \& Appah, E. (2012). Impact of Tax Reforms and Economic Growth in Nigeria: A Time Series Analysis. Current Res. J. Soc. Sci., 4(1), 62-68.

Ojong, C. M., Anthony, O., \& Arikpo, O. F. (2016). The impact of tax revenue on economic growth: Evidence from Nigeria. Journal of Economic and Finance, 7(1), 32-38.

Okeke, M. N., Mbonu, C. M., \& Ndubuisi, A. N. (2018). Tax revenue and economic development in Nigeria: A disaggregated analysis. International Journal of Academic Research in Accounting, Finance and Management Sciences, 8(2), 178-199.

Okwara, C. C., \& Amori, O. M. (2017). Impact of tax revenue on economic growth in Nigeria. International Journal of Advanced Scientific Research, 2(2), 90-102. Retrieved from http://internationalpolicybrief.org/journals/ijasr-online-journals/intl-jrnl-of-sci-research-in-social-sciencesmgt-studies-vol2-no2-dec-2017

Onaolapo, A. A., Aworemi, R. J., \& Ajala, O. A. (2013). Assessment of value added tax and its effects on revenue generation in Nigeria. International Journal of Business and Social Science, 4(1), 220-225.

Oyedele, T. (n. d.). Guess how many Nigerians pay tax and how our government spends the money, PWC@. Retrieved from http://www.pwc.com

Solow, R. M. (1956). A contribution to the theory of economic growth. Quarterly Journal of Economics, 70, 65-94. https://doi.org/10.2307/1884513

Uzoka, P. U., \& Chiedu, C. O. (2018). Effect of tax revenue on economic growth in Nigeria. International Journal of Social Sciences and Management Research, 4(7).

Worlu, C. N., \& Emeka, N. (2012). Tax revenue and economic development in Nigeria: A macro econometric approach. Academic Journal of Interdisciplinary Studies, 21(46), 121-139.

\section{Copyrights}

Copyright for this article is retained by the author(s), with first publication rights granted to the journal.

This is an open-access article distributed under the terms and conditions of the Creative Commons Attribution license (http://creativecommons.org/licenses/by/4.0/). 